\title{
Marketing Study Abroad Programs: A Student Recruitment Model
}

Vaidas Lukosius, Tennessee State University, USA

Troy A. Festervand, Middle Tennessee State University, USA

\begin{abstract}
The number of American students studying abroad increases every year. That might suggest that recruiting students to participate in such an educational opportunity would present little difficulty. On the contrary, as domestic student participation in such programs has risen, so has the number of competing programs. Thus, the viability of any study abroad program, to a large extent, is a direct result of that program's recruiting effort. The foundation of that recruiting effort should be based upon an understanding of the factors students deem important in the program selection process and an effective promotional effort focused on those issues. These key factors include student segment(s) to be targeted, program cost and source(s) of funding provided, timing and duration of the program.
\end{abstract}

Keywords: Study Abroad; Marketing; Recruitment; Segmentation; Funding; Timing

\section{INTRODUCTION}

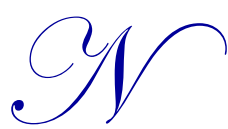

early three decades ago, Berendzen (1981) noted that "Americans have, overall, an abysmal lack of understanding about foreign cultures." In part, these shortcomings provided the impetus for a change in the American Assembly of Collegiate Schools of Business (AACSB) accreditation standards to include the internationalization of curriculum as a key aspect of business education, both graduate and undergraduate. However, this heightened awareness of the importance of the international marketplace, as well as academic mandate, has not always translated into international success. Goodman (1999) observed that even though American understanding of foreign cultures is getting better, expatriates tend to fail in international settings because of prevailing cultural adjustment related issues.

Due to such issues, international education opportunities (typically referred to as "study abroad programs"), have increased dramatically in number and scope. Today, almost all US universities, large and small, urban and rural, private and public, have established or are in the process of establishing international study abroad programs and even "(m)ore universities are making commitments to expand their global exposures so students can participate in a global society" (Ray \& Ryder, 1995). A survey by the Institute of International Education (2011) found steady growth in the number of students participating in study abroad programs. Over 270,000 study abroad students have earned academic credit at their home institution in 2010/11 academic year. The number of programs and schools that are engaged in such activities is also increasing. This can be attributed to a number of reasons: preparing competent business leaders (Hulstrand, 2007), increased intercultural proficiency (Clarke, Flaherty, Wright, \& McMillen, 2009; Deardoff, 2006), increased learning (Holoviak, Verney, Winter, \& Holoviak, 2011) and respond to the needs of the private sector, where companies realize that they do need employers capable of working in highly international environment dealing with culturally diverse workforce (Peppas, 2008).

Study abroad programs should be looked as "complementary means to offer a rounded education, by allowing participating business students to gain international exposure" (Ortiz, 2004, p. 264). Classes, offered as a study abroad program are evaluated more highly than those offered at home, students report changes in their worldview, self-reflection, and cross-cultural understanding (Budden, Baraya, \& Juban, 2005). Importance of worldview expansion is universal. For business students, this is a preparation for international business careers; for language students, this is a better understanding of living and breathing language; for media and communication students, it opens grounds for better contextual understanding of social and technological change. 
The purpose of this article is to discuss a targeted student recruitment model concerning how short-term study abroad programs have been, and perhaps should be promoted/marketed to students who participate in study abroad programs on a voluntary basis. The intent of this article is to offer insight and suggestions to academic administrators and professors interested in developing an international educational experience directed toward such a target market. In addition to discussing marketing recruitment strategies, numerous operational and tactical issues are identified and discussed.

\section{CONCEPTUAL FRAMEWORK}

Over three decades ago, Beamish and Calof (1989) put forth the idea that internationally oriented education system is vital for economic health of a country. A number of scholars have quantified and identified specific goals for higher education. International education system helps students to develop necessary critical thinking skills to move past their inherent cultural biases (White \& Griffith, 1998). Similarly, Goodman (1999) pointed that in maturing American marketplace, commerce is the basis on which cross-cultural learning takes place.

Delivery of education in international study abroad programs has unique cultural implications. For example, international marketing course delivered in Sweden, was effective when case methods, exercises and guest speakers were used (Wilson \& Balfors, 1995). Chan (1989), on the other hand, found that delivery of such courses in China is best accomplished by less formal in-depth discussions. To create a more innovative and globally interactive learning approach, Fish, Martinez, Santillan, and Brazell (1998) took a group of students from multiple cultures and used internet resources with case-group teaching method. Since such approach is based on extended and frequent interaction between students with different cultural background, transfer of marketing knowledge can be maximized. Thus, effectiveness of delivery methods varies by the educational context in which it takes place.

Geographic factors are equally important in international business education. Greatest amount of multicultural experience is achieved by implementing a multi-city program (Gordon \& Smith, 1992; Schuster, 1993). Such approach, while popular with the students, however, not only is complex from logistical perspective and increased financial burden, but also has issues in terms of depth of knowledge acquired. To minimize such concerns, Brokaw (1996) outlined single-city approach, where home campus classes are combined with rather intensive cultural immersion experience.

A large body of literature suggests that the effectiveness of alternative learning approaches largely varies by the type of course offered and by the learning objectives to be achieved (Boronico \& Boronico, 2010; Burnett \& Pettijohn, 1999; Celuch \& Slama, 1998; Erffmeyer \& Al-Khatib, 1997; Fisk, 1990; Frontczak, 1998; Hugstad, 1997; Kaynaka \& Kucukemiroglub, 1997; Ramocki, 1996; Strauss \& Frost, 1999; Swan \& Hansen, 1996; Wellington, Faria, \& Nulsen, 1996; Zych, 1997). In light of these recommendations, it appears that the actual course delivery mechanism can only be decided once the overall context in which it is offered has been considered.

In an academic setting, study abroad program recruitment should be somewhat selective. Jochems, Snippe, Smid, and Verweij (1999) suggest that two factors define success of students in international academic settings: a higher level of language proficiency and selective choice of students. Dickson and Segars (1999) advanced perspective to international education by suggesting for faculty to utilize the opportunities that the international environment presents, tap new technology-enabled teaching environments, and rethink and modify teaching assumptions as well as paradigms.

Compounding the complexity of issues surrounding the design and conduct of study abroad programs is their classification as unsought services. Put simply, students don't know what they want or need until after they learn about it. Further, because study abroad programs meet the service criteria of intangibility, inseparability, and uniqueness, these products/services are higher in perceived risk and will create distinctive information needs in students (or consumers) (Murray, 1991).

While numerous questions, issues, and decisions (such as the preceding) must be addressed regarding the operational specifics of all study abroad programs, one factor is common and critical to all programs: students. Coordinators of all programs must, therefore, answer several questions vital to the programmatic and economic 
viability of all programs. For example, from what source(s) will students be recruited? What type(s) of students will be recruited? How does program cost affect student recruitment? How does course and destination programming impact student recruitment? When should program be conducted?

Figure 1 presents an overview of the components of proposed model. While the factors/areas identified in the proposed model play an integral role in student recruitment, it is recognized that a plethora of factors contribute to the study abroad decision and are not depicted in the proposed model.

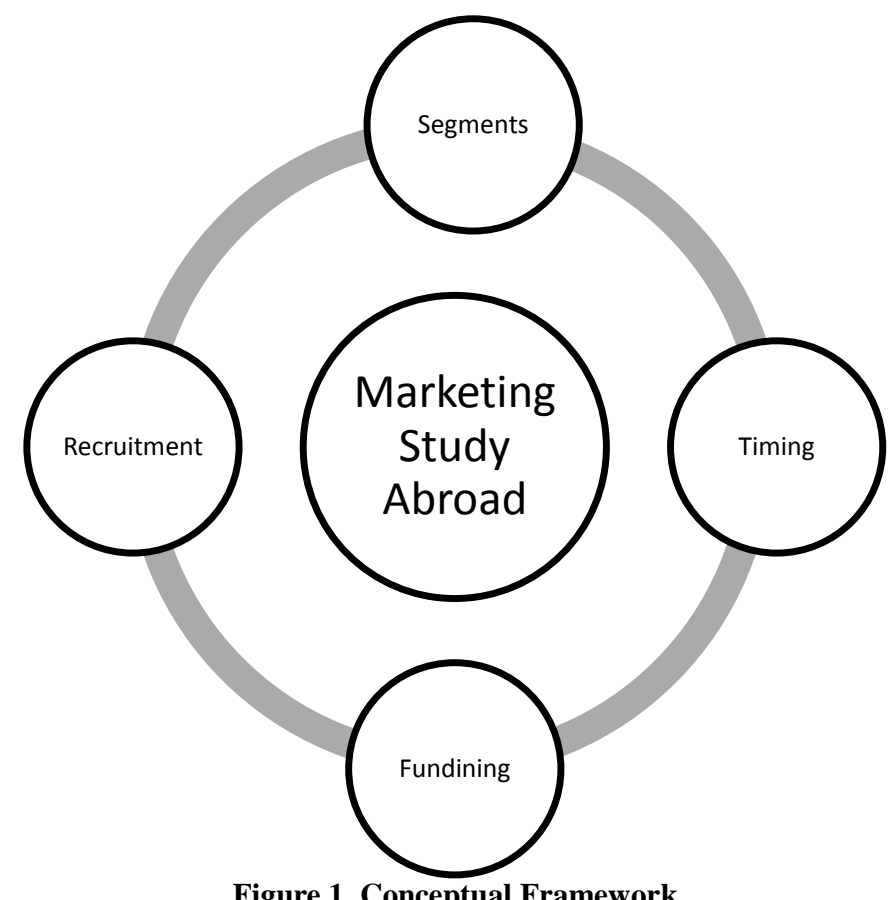

Figure 1. Conceptual Framework

\section{SEGMENTS TARGETED}

Many universities conduct short-term international trips appealing to students across a range of disciplines (e.g., Mills, Deviney, \& Ball, 2010; Schwald, 2012). Social science majors represent the largest group of study abroad students, business and management majors are second, and humanities majors are third (Ortiz, 2004). In some international exposures, both undergraduate and graduate students at the sponsoring and affiliated institutions are targeted. In addition to demographically expanding the target markets, course offerings normally span several disciplines in order to attract the greatest number of participants.

Several advantages are associated with this approach to target audience selection. First, the relatively homogeneous background of these students makes possible a high level of concentrated academic content. Second, by focusing on both undergraduate and graduate students at multiple state institutions, the university's image and reputation are enhanced. Further, many courses, especially upper level undergraduate courses, may be cross-listed as graduate courses, thus greatly increasing the size of the potential student pool. It also may be the case that participating upper division undergraduate students return to their home institutions and are poised to become future graduate students because of the experience and relationships formed. Finally, participating students return to their respective campuses and become ambassadors who share their experiences and promote the university and program to others. The following segments* are identified as having higher probability of participating in study abroad programs:

1. Upper division/graduate students - Because they tend to be older and more mature, these students often are more responsible and their educational preparation and expectations are more consonant with the nature and character of this international experience. As previously noted, many courses 
can be cross-listed, so both groups of students are candidates for the same class. While limited, these students often have or can more readily acquire the necessary financial resources relative to younger or lower division students. Further, because of their maturity, many of the problems often linked to younger students may be avoided.

2. General education students - All universities and academic programs require students to complete a curriculum of basic education. In most instances, this core curriculum consists of basic courses in science, English/literature, history, psychology, foreign language, etc., all of which are excellent offerings for international study. Because these courses are required of all undergraduate students, freshman and sophomore level students may comprise the largest market segment targeted. However, as previously noted, a trade-off between market size and market maturity exists, thus potentially limiting the attractiveness of this segment.

3. Female students - In the 2009/10 academic year, women accounted for almost two-thirds of all American students studying abroad (Chronicle of Higher Education, 2012). For example, Stroud (2010) showed that female students, living away from home, and those wanting to improve their understanding of other cultures were more likely to intend to study abroad. Rephrased, male students participate in study abroad programs at half the rate of their female counterparts (Lucas, 2009). Consequently, while both male and female students should be recruited, most attention should be directed toward females.

4. Junior/Community College students - An often overlooked arena from which to draw study abroad students is the junior/community college market. Perhaps because these students are not readily accessible to study abroad faculty or are not current students at 4-year institutions, this market offers potential for virtually any study abroad class. These students need basic and mid-level courses, as well as upper division courses for those students going on to four-year institutions. Further, funding in many states to 2-year programs often includes specific set-aside funding for international study, which may cover most, if not all, study abroad expenses.

5. Students majoring in subject to be taught - Whether the course to be taught is in business, art, literature, history, or any/all other areas, perhaps the most obvious and productive student to recruit is the student majoring in the field. In addition to having a positive predisposition toward the subject, the recruiter has ample time and opportunity to market the course and program. Being involved and instrumental from the beginning of the decision-making process all the way through the final decision can yield powerful dividends to the entire study abroad program.

*It is important to note that these segments are not mutually exclusive and do overlap.

\section{COST/FUNDING}

Jong, Schnusenberg, and Goel (2010) and He and Banham (2011) found that students report two key program attributes, cost and location, as most significant when deciding on a program and qualitative analysis in Bakalis and Joiner (2004) revealed that the cost of study abroad programs is an important factor. In fact, Doyle, et al. (2009) demonstrated that a key obstacle for not going abroad is lack of funding, while a key reason for a program's attractiveness is financial support in the form of a scholarship. Financial component is an essential part of a study abroad program because most associated activities require financial support. Before a program is marketed, a number of budget-related questions should be answered, as each will impact funding and overall costs.

\section{Overall Program Cost}

For the student, the cost to participate has four major components. The first and largest cost component is the basic program cost. This typically includes transportation (usually airfare), accommodations, meals, excursions, etc. This is the dollar amount identified in promotional literature that is associated with a particular study abroad program. The second cost component is tuition. Tuition may or may not be included in basic program cost. Therefore, program cost of $\$ 5,000$ can be increased significantly (e.g., tuition for 2 courses of $\$ 3,000$ plus basic cost of $\$ 5,000=\$ 8,000$ or a $60 \%$ increase) if tuition is not included. The third cost component is the amount the student pays for the program out of pocket before departure. Items such as passport application fees, visa, medical insurance, etc. may be absorbed by each student, often exceeding between $\$ 300$ and $\$ 400$. The fourth cost 
component is comprised of any additional cost that is paid by the student while participating in the program (discretionary spending). On-site expenditures typically include additional meals, souvenirs, shopping, personal travel, etc. For some participants, this cost can equal overall program cost, while for others, this cost can be minimal.

Numerous programming decisions can be made as to lower or increase the program cost. For example, program location has a tremendous impact upon program cost. Mercer (2012) indicates that cities, such as Tokyo, Moscow, São Paulo are expensive locations for a study abroad program. Hotels, meals, transportation, etc. are all very costly, but the locations are highly desirable. In some instances, location cost can be ameliorated by using alternative housing (e.g., dorms rather than hotels). Other cost related decisions/options include public versus private transportation, optional/fewer excursions, shorter programs, multiple occupants in rooms, etc.

A total monetary cost of study abroad experience is the sum of four components. The first three components can be easily calculated and presented, while the fourth component, discretionary spending, can only be estimated as it will vary dramatically between individual students. These latter expenditures are largely unplanned and a variety of factors can lead to increased spending behavior (Wood, 2005).

\section{Student Share}

A student's financial commitment to the program is essential, as their payments represent a large part of, if not the totality of program revenue. Program revenue then becomes the starting point for developing the program budget. Surprisingly, a key question often asked is "How much should a student contribute to a study abroad program?" Contribution can range from $0 \%$, where a student is fully funded by an institution or an outside agency, to $100 \%$, where a student pays for the entire program out of pocket. Anecdotal evidence suggests that the relationship between the contribution amount and program involvement is linear. The more the student pays, the more intrinsically involved and committed students become.

\section{Internal and External Funding Sources}

Study abroad program funding can be classified into several categories. Internally, a university's central administration represents a significant source of funding. A portion of tuition collected from foreign students often is earmarked for international experiences, while in other instances, a portion of all tuition or an additional fee is collected and earmarked for distribution to study abroad students.

State appropriations for most universities include dollars dedicated to/for international education. These dollars may be allocated by a Provost or VP for International Education, but they typically are available. Similarly, any/all Study Abroad offices have budgets that include tuition offsets, reductions in study abroad program costs. These can range from a few dollars to the total cost of the program depending upon the number of participants. These monies may be competitively sought after, but any effort generally is rewarded.

Study Abroad scholarships can be internal or external. These monies can be modest in amount or quite significant. Some scholarships are dedicated to a certain group of students (e.g., music majors) or open for all. More aggressive programs often seek outside support for a study abroad program. Foreign firms operating within the US are approached about providing an annual scholarship for a student(s) attending a study abroad program in the home country of that firm. For example, Nissan and Bridgestone, both Japanese multinational firms, have been receptive to supporting study abroad programs targeting Japan and the Pacific Rim. Following that logic, Volkswagen, BMW, and Mercedes would be more receptive to Germanic programs, while Michelin may be more likely to support a French educational effort.

Can financial aid be used to fund study abroad? Yes, but those costs often bear interest and must be repaid. While the experience may well be worth the cost, it remains a debt to be repaid and may diminish the quality of the overall study abroad experience. Additionally, the process of obtaining financial aid for a specific time period, such as summer, bears additional stipulations, where student is required to take a certain minimum number of credit hours. 


\section{TIMING/DURATION}

When planning a study abroad program, two timing-related issues are of critical importance: 1) the starting date of the program; and 2) the duration of the program. These temporal issues are particularly significant for financial reasons, as well as if the study abroad pool consists of working adults.

\section{Program Starting Date}

The starting date of study abroad programs is generally related to the academic schedule of the institution. Short term study abroad programs sometimes are conducted during the academic break between semesters (winter/spring) or within a semester (fall break, spring break). Programs of 10 days or less within a semester generally do not provide sufficient time to conduct a program unless the course is intensive and pre-trip work has been completed. A notable exception to the preceding axiom is an Executive MBA program that often requires its participants to attend such a short-term foreign experience as part of the overall curriculum (e.g., www.memphis.edu/executivemba).

Most short term study abroad programs take place in summer months. As such, program commencement can be at any point following final exams (e.g., 1st week of May). Unless the study abroad program runs the entire summer, three temporal periods typically characterize study abroad programs. For many programs, this "Maymester" or "mini-mester" lasts 3 weeks and starts as soon as the spring semester ends and concludes at the end of May, prior to the start of many resident summer school sessions. This format is particularly attractive for budget programs (i.e., shorter time period equals lower cost), as well programs whose participants work full-time.

\section{Program Duration}

Traditional summer study abroad programs last for a month to six weeks. The Kentucky Institute for International Studies (KIIS), found at www.kiis.org, offers a variety of such programs. Available in a number of countries, KIIS' programs typically target full-time students, allow students to complete 6 hours of academic credit, and minimize costs via in-home stay and limited, paid excursions. Still other programs operate on a six week basis. For example, the University of New Orleans' Division of International Education, found at www.inst.uno.edu, will conduct its $37^{\text {th }}$ annual study abroad to Innsbruck, Austria, in 2013. That program, with a six weeks format, also targets full-time students at major southern universities and provides ample opportunity for individual travel and exploration.

An entire semester of study abroad also is an option. Whether over the summer or a Fall/Spring semester, such an experience typically is limited in program size and targets a select group of participants (e.g., foreign language majors). In many instances, such programs take the form of an exchange program, as opposed to the typical study abroad program.

As can be seen from the pre ceding discussion, the duration of the program is a critical factor and decision, as time affects academic standards, as well as a multitude of programmatic issues for the program directors, faculty, and students. Listed below are some of the key temporal issues that need to be considered:

1. Accredited institutions required that 37.5 hours of contact time has to be maintained for a 3 credit hour course (SAACS/AACSB). 21 day program can follow the following format: 4 days of backto-back lecturing with 3 days break, which comes out to 12 teaching days.

2. As the length of the program increases, the likelihood that a working student can participate decreases.

3. Timing is also important when considering special days in host country. For example, Cherry Blossom Festivals in Japan in April could create logistical issues. Similarly, during mid-summer festivals in Scandinavian countries in June majority of the population travels to the Northern areas of the countries.

4. Logistically, the duration of stay in some countries (e.g., France) may be subject to restrictions on the length of stay, which creates a mandatory relocation situation for the group. 
5. The length of the program is directly related to variable costs of the program (e.g., in-city transportation, food, accommodations, etc.).

\section{PROMOTION/MARKETING}

The promotion of any study abroad program is one key activity that should be planned and prepared for ahead of time. Short term study abroad programs, especially those conducted in the summer, compete with other substitute experiences. Students have variety of options, such as enjoy their hobbies, try out future carrier by either working or interning, advance academically by taking summer classes, volunteering etc. Therefore, planning and implementing a recruitment campaign should be a yearlong process.

Promoting study abroad programs pose unique challenges because the service is in the form of an educational experience. Thus, it should be treated as a service package, including "a bundle of goods and services with information that is provided in some environment" (p. 22) (Fitzsimmons \& Fitzsimmons, 2011). Students (or consumer) are likely to use the following evaluative criteria:

1. $\quad$ Supporting facilities, e.g., housing and transportation conditions abroad;

2. Facilitating goods and services, e.g., ability to visit multiple sites while abroad;

3. Information, e.g., faculty knowledge about subject and countries to be visited;

4. Explicit services, e.g., accuracy and quality of content and delivery of course/subject material abroad;

5. Implicit services, e.g., faculty attitude and rapport with students.

Mason (2005) suggests that unsought goods are "purchased when a sudden problem arises or when aggressive selling is used to obtain a sale that would otherwise not take place" (p. 317). Successfully marketing study abroad program as an unsought good requires careful planning and monitoring of promotional activities.

To better promote study abroad programs, an understanding of the key factors that drive student choices is necessary. Once in hand, appropriate promotional tools and strategies can then be employed. There are a number of theoretical frameworks that explain consumer choices (e.g., Solomon, 2012), and in this particular case, students go through a modified decision making process (Chapman, 1986). Maringe (2006) suggests that there are five stages that prospective students go through when choosing an academic institution, but these steps can be modified and adopted for study abroad experience. The framework to consider for promotional purposes is as follows:

1. Pre-search behavior: In this stage, students passively absorb the information about study abroad and are developing attitudes toward the program.

2. Search behavior: Students have a list of potential academic programs in selected countries that they want to learn more about. They make up their minds while looking for data as it relates to their decision criteria.

3. Choice and Application stage: At this stage, formal application is made to participate in study abroad program in a specific academic field. Typically, a number of supplemental materials, such as transcripts, letters of support and recommendation, medical surrogacy and consent forms, behavioral contract are submitted.

4. Registration and Payment: Finally, accepted applicants register for a particular course at the institution, and make the final payment for the cost of the program.

To couple promotional strategies with sequential decision making process, several options can be suggested. In the first, pre-search behavior stage, students have to be made aware of the programs and become interested. To build awareness, study abroad programs have to be made public at the institutions. It can be achieved by variety of means: using social media, such as Facebook or Twitter, creating branded websites, conducting study abroad fares, publicizing student ambassadors, etc. For example, Tennessee Consortium for International Studies (TnCIS), found at www.tncis.org, is a branded website providing ample amount of information and resources for students wanting to go and study abroad. Information presented here should be generic, outlining the basic parameters of study abroad program. 
In the second stage, aware students are building interest and begin to search for more information. At this point, more detailed information about academic and cultural programs, the countries, and faculty teaching courses should be presented. More specifically, Jong et al. (2010) break down and list the attributes that are considered important: a) location and cultural program, b) cost, c) academic programs, d) timing, e) faculty. Each attribute should be mentioned and addressed when presenting the study abroad experience. For example, flyers with specific details should be developed and disseminated in the classrooms and by bulletin boards. Institutions should enlist International Education Offices (or similar units) to spread this information more effectively. Additionally, if there are sources of financial support or funding from a home institution, the application process should be clearly explained and outlined. Building interest can also be done by pointing out specific benefits, such as, employers valuing study abroad experience and looking at it as competitive attribute on resumes (Trooboff, Berg, \& Rayman, 2007).

The last two stages involve bureaucratic processes and knowledge of proper procedures is required. At this point, committed students are simply following the necessary steps to be admitted and to stay in the program. Faculty's knowledge of administrative procedures should reduce the number of students dropping out.

For the experienced study abroad leader, recruiting and promoting a study abroad program are virtually synonymous. As such, the promotional process for a study abroad program is not that dissimilar from the promotion that would accompany any new product. In most instances, a limited, but fundamental set of promotional rules/tools/strategies (RTS) are employed. Those RTS include the following:

1. Start early and develop an integrated marketing communications (IMC) plan;

2. $\quad$ Promote constantly and consistently (do not make a final "big push" just before the deadline);

3. Consistent with the IMC plan, use multiple methods of promoting;

4. Promote all salient aspects of the program: course, location, outcomes, cost, etc.;

5. Be aggressive - attend multiple events, appeal to multiple senses and emotions;

6. Sell memories - ultimately the real driver of the decision making process are the memories to be made.

\section{CONCLUSION}

Today, more so than ever before, it is absolutely critical that students study and experience the international environment. In addition to the experiential learning that occurs from on-site visitations and presentations, students will experience cultural diversity at the macro and micro levels. This acculturation process will reshape how they view the world, its people, and its marketplace. However, in order for these benefits to accrue, students must participate and that translates into recruiting. This essay has attempted to address this topic in a myriad of ways.

Marketing, thus promotion, of study abroad programs is crucial to the success of any and all programs. Over the years, the authors of this essay have observed a number of study abroad programs succeed and fail. While the successes more often are the result of thorough planning and delivery, some of the failures enjoyed similar levels of planning and delivery. If that is the case, then why do we see the difference?

In some instances, the answer is rather simple. Some programs never got started, they did not make. Every study abroad program has its own break-even point. At a certain price point to participate, there is a minimum number of students required for the program to make. If these numbers are not achieved, then like many new products that offer new experiences, some never see the light of day. More often than not, it is a failure to market the product to the customer.

While largely anecdotal, marketing practices, such as presentation of promotional materials with pertinent program information (e.g., itinerary, applications, funding sources, etc.), showing a video featuring study abroad students sharing their experiences, bringing artifacts from foreign countries, speaking to students on a frequent basis, all were significant opportunities that may have led to a positive decision, thus higher enrollment, a more positive attitude, and increased student engagement. 
Based on literature reviews and informal discussions with students, factors, such as program cost, duration, countries to be visited, course requirements, etc. were some of the attributes that students perceived as important in their decision to go on a study abroad program. These factors then become the focus of promotional efforts designed to attract students into these programs. Where once it was possible for an entrepreneur to simply "hang out his/her shingle," those days and that marketing mentality no longer is adequate. Effective student recruitment for a study abroad program requires careful thought, a dedicated plan, and vigilance throughout the recruitment process.

\section{AUTHOR INFORMATION}

Vaidas Lukosius has PhD. from New Mexico State University, a M.Sc. from Helsinki University of Technology. Currently, he is on the faculty at Tennessee State University where he is teaching marketing courses. Dr. Lukosius' current areas of specialization include international and online marketing education, marketing research, and video game consumption behavior. E-mail: Vlukosius@tnstate.edu

Troy A. Festervand is Associate Dean of Graduate and Executive Education and Professor of Marketing in the Jennings A. Jones College of Business at Middle Tennessee State University (MTSU) in Murfreesboro, Tennessee. In addition to being the former Editor of the Journal of Diversity Management, his research has appeared in over a hundred scholarly journals and on the programs of many professional conferences. Professor Festervand's teaching specialties include International and Industrial Marketing. E-mail: Troy.Festervand@mtsu.edu (Corresponding author)

\section{REFERENCES}

1. Bakalis, S., \& Joiner, T. A. (2004). Participation in Tertiary Study Abroad Programs: The Role of Personality. International Journal of Educational Management, 18 (5), 286-291.

2. Beamish, P. W., \& Calof, J. L. (1989). International Business Education: A Corporate View. Journal of International Business Studies, 20 (3), 553-564.

3. Boronico, C., \& Boronico, J. (2010). Study Abroad Perspectives on Institutional Operations. Contemporary Issues in Education Research, 3 (4), 13-20.

4. Brokaw, S. C. (1996). Planning, Organizing and Executing Short Term International Exposures for Us Students of Marketing and Business: An Alternative Method. Marketing Education Review, 6 (3), 87-94.

5. Budden, M. C., Baraya, A. R., \& Juban, R. L. (2005). Developing an MBA Study-Abroad Program at Southeastern Louisiana University. Business Communication Quarterly, 68 (2), 233-236.

6. Burnett, M. S., \& Pettijohn, C. (1999). Improving Student Performance through Student Mentorships: Practices, Prescriptions and Policies for Enhanced Learning. Marketing Education Review, 9 (1), 61-70.

7. Celuch, K., \& Slama, M. (1998). Critical Thinking as an Integrative Theme for Teaching Lifelong Learning Skills in Marketing. Marketing Education Review, 8 (3), 1-12.

8. Chan, S. (1989). Teaching Marketing in China: Implications for Effective Marketing Education. Journal of Teaching in International Business, 1 (1), 33-46.

9. Chapman, R. (1986). Towards a Theory of College Selection: A Model of College Search and Choice Behaviour. In R. J. Lutz (Ed.), Advances in Consumer Research (Vol. 13). Provo, Utah: Association for Consumer Research.

10. Clarke, I., Flaherty, T. B., Wright, N. D., \& McMillen, R. M. (2009). Student Intercultural Proficiency from Study Abroad Programs. Journal of Marketing Education, 31 (2), 173-181.

11. Deardoff, D. K. (2006). Identification and Assessment of Intercultural Competence as a Student Outcomes of Internationalization. Journal of Studies in International Education, 10 (3), 241-266.

12. Dickson, G. W., \& Segars, A. (1999). Redefining the High-Technology Classroom. Journal of Education for Business, 74 (3), 152-156.

13. Doyle, S., Gendall, P., Meyer, L., Hoek, J., Tait, C., McKenzie, L., \& Loorparg, L. (2009). An Investigation of Factors Associated with Student Participation in Study Abroad. Journal of Studies in International Education, 14 (5), 471-489.

14. Erffmeyer, R. C., \& Al-Khatib, J. A. (1997). Students' Study Abroad Experiences: Gaijin in Japan. Marketing Education Review, 7 (1), 63-69. 
15. Fish, K. E., Martinez, C. R., Santillan, R. J., \& Brazell, J. D. (1998). International Marketing Internet in the Classroom (IMIC): A Global Approach to the Group Case Method. Marketing Education Review, 8 (2), 7582.

16. Fisk, R. (1990). Reflections on Teaching Marketing in Austria. Marketing Education Review, 1 (1), 77-80.

17. Fitzsimmons, J. A., \& Fitzsimmons, M. J. (2011). Service Management: Operations, Strategy, Information Technology (7 ed.). New York, NY: McGraw-Hill.

18. Frontczak, N. T. (1998). A Paradigm for the Selection, Use and Development or Experiential Learning Activities in Marketing Education. Marketing Education Review, 8 (3), 25-33.

19. Goodman, A. E. (1999). America Is Devaluing International Exchanges for Students and Scholars. The Chronicle of Higher Education (A56).

20. Gordon, P., \& Smith, D. K. (1992). Planning, Organizing, and Executing Short Term International Exposures for U.S. Students of Marketing and Business: An Alternative Method. Marketing Education Review, 2 (1), 47-53.

21. He, Y., \& Banham, H. (2011). Education Destination Determinants of Chinese Students. Journal of International Education Research, 7 (4), 19-32.

22. Holoviak, J., Verney, T., Winter, A., \& Holoviak, S. (2011). Assessing Academic Performance through Study Abroad: Benefits of the Experience. In Research in Higher Education (Vol. 11): Academic and Business Research Institute.

23. Hugstad, P. (1997). Marketing the Marketing Major. Journal of Marketing Education, 19 (4), 4-13.

24. Hulstrand, J. (2007). Educating for Global Business. International Educator, 16 (5), 36-41.

25. Jochems, W., Snippe, J., Smid, J. H., \& Verweij, A. (1999). The Academic Progress of Foreign Students: Study Achievement and Study Behavior. Higher Education, 31, 325-325.

26. Jong, P., Schnusenberg, O., \& Goel, L. (2010). Marketing Study Abroad Programs Effectively: What Do American Business Students Think? Journal of International Education in Business, 3 (1/2), 34 - 52.

27. Kaynaka, E., \& Kucukemiroglub, O. (1997). Program and Curriculum Development in International Marketing in an Emerging Economy. Journal of Teaching in International Business, 9 (1), 51-71.

28. Lucas, J. M. (2009). Where Are All the Males? A Mixed Methods Inquiry into Male Study Abroad Participation. Michigan State University, East Lansing, MI.

29. Maringe, F. (2006). University and Course Choice: Implications for Positioning, Recruitment and Marketing. International Journal of Educational Management, 20 (6), 466-479.

30. Mason, R. (2005). Missing Links: Product Classification Theory and the Social Characteristics of Goods. Marketing Theory, 5 (3), 309-322.

31. Mercer. (2012). Mercer Worldwide Cost of Living Survey. Retrieved from http://www.mercer.com/pressreleases/cost-of-living-rankings

32. Mills, L. H., Deviney, D., \& Ball, B. (2010). Short-Term Study Abroad Programs: A Diversity of Options The Journal of Human Resource and Adult Learning, 6 (2), 1-13.

33. Murray, K. B. (1991). A Test of Services Marketing Theory: Consumer Information Acquisition Activities. Journal of Marketing, 55 (1), 10-25.

34. Ortiz, J. (2004). International Business Education in a Global Environment: A Conceptual Approach. International Education Journal, 5 (2), 255-265.

35. Peppas, S. C. (2008). Business Study Abroad Tours for Non-Traditional Students: An Outcomes Assessment. Frontiers: The Interdisciplinary Journal of Study Abroad, 11 (August), 143-163.

36. Ramocki, S. P. (1996). Developing Creative Marketing Graduates. Marketing Education Review, 6 (1), $47-$ 53.

37. Ray, N. M., \& Ryder, M. E. (1995). Discussing Snow with the Eskimos: A Course in Language Issues in Multicultural Business. Marketing Education Review, 5 (63), 61-72.

38. Schuster, C. P. (1993). Planning and Implementing Overseas Travel Classes for Executive Mba Students. Marketing Education Review, 3 (3), 54-60.

39. Schwald, R. (2012). Toward a New Practice of Internationalization: A Case Study on a Short-Term Study Abroad Program at European Institutions of Higher Education Review of European Studies, 4 (2), $44-55$.

40. Solomon, M. R. (2012). Consumer Behavior (10 ed.). Upper Saddle River, NJ: Prentice Hall.

41. Strauss, J., \& Frost, R. (1999). Marketing on the Internet: Principles of Online Marketing. Upper Saddle River, NJ: Prentice-Hall. 
42. Stroud, A. H. (2010). Who Plans (Not) to Study Abroad? An Examination of U.S. Student Intent. Journal of Studies in International Education, 14 (5), 491-507.

43. Swan, J. E., \& Hansen, S. W. (1996). Caps-Client Adaptive Problem Solving: Experiential Team Learning. Marketing Education Review, 6 (2), 33-44.

44. Trooboff, S., Berg, M. V., \& Rayman, J. (2007). Employer Attitudes toward Study Abroad. Frontiers: The Interdisciplinary Journal of Study Abroad, 15 (Fall/Winter), 17-33.

45. Wellington, W., Faria, A. J., \& Nulsen, J. R. O. (1996). An Empirical Investigation into the Nature of the Learning Process in a Computer-Based Simulation Game. Marketing Education Review, 6 (3), 15-28.

46. White, D. S., \& Griffith, D. (1998). Graduate International Business Education in the United StatesComparisons and Suggestions. Journal of Education for Business, 74 (2), 103-115.

47. Wilson, T., \& Balfors, G. (1995). Design and Conduct of a Graduate International Marketing/Business Course in Sweden. Marketing Education Review, 5 (Spring), 50-60.

48. Wood, M. (2005). Discretionary Unplanned Buying in Consumer Society. Journal of Consumer Behaviour, 4 (4), 268-281.

49. Zych, J. M. (1997). Adding Case Materials to Reinforce the Realism in Marketing Simulations. Marketing Education Review, 7 (2), 51-61. 
NOTES 